\title{
Study of Electrical Discharge Machining Parameters on Stainless Steel Using Copper Tool Electrode and Its Effect on the Structure and Electrochemical Properties
}

\author{
Mozhgan Karimi, Sayyed Ahmad Nabavi-Amri* and Ahmad Soleymanpour \\ School of Chemistry, Damghan University, Damghan 3671641167, Iran \\ *Corresponding author: E-mail:nabavi@du.ac.ir \\ Tel/Fax: +982335220095
}

Received: 03-18-2020

\begin{abstract}
In this work, the effect of the presence and the diffusion of the Copper from the tool electrode onto the EDMed stainless steel (SS) surface have been investigated by electrochemical impedance spectroscopy (EIS), X-ray diffraction (XRD), Quantometer analysis, and Optical microscopic observations. The Taguchi method was used to study the effects of Pulseon time $\left(t_{\text {on }}\right)$, Pulse-off time $\left(t_{\text {off }}\right)$, discharge current $(I)$, and overall machining time $(\tau)$ on chemical composition, microstructures, micro-cracks, and electrochemical corrosion of EDMed stainless steel workpieces. The results show that the variation of machining parameters changes the chemical composition of the workpieces. By increasing the discharge current and decreasing the Pulse-on time, the copper and the carbon diffuse onto the surface of the workpiece. Consequently, the chemical composition of the workpiece surface changes, leading to an increment of the corrosion resistance. The XRD analysis shows the formation of $\mathrm{Fe}_{2} \mathrm{C}, \mathrm{Cr}_{3} \mathrm{C}_{2}$, and $\mathrm{CuNi}$. In addition, at higher values of discharge current and $t_{\mathrm{on}} / t_{\mathrm{off}}$ ratio, the micro-cracks propagate on the surface of the workpiece.
\end{abstract}

Keyword: Electrical discharge machining; Stainless steel; Electrochemical impedance spectroscopy; Electrochemical corrosion; Copper diffusion

\section{Introduction}

Electrical discharge machining $(\mathrm{EDM})$ is one of the most effective processes that can produce high-quality materials precisely with a wide range of strength, hardness, and shape. ${ }^{1,2}$ In the EDM process by applying an electrical potential between the workpiece and the tool electrode immersed in a dielectric solution a discharge current is created. Then the discharge current overcomes the dielectric solution resistance and is discharged in the form of sparks on the workpiece surfaces. However, each of these sparks can act as a source of heat. So, the local temperature can increase to more than $10000{ }^{\circ} \mathrm{C}$ at the micro-second time intervals. ${ }^{3,4}$ Hence, the temperature gradient developed on the surface of the workpiece leads to melting and changing material constituents, ${ }^{5}$ as well as diffusion of very small particles to the surface of the tool electrode ${ }^{6}$, and Hence changing the mechanical, ${ }^{7,8}$ structural ${ }^{9}$ and electrochemi$\mathrm{cal}^{10}$ properties of the workpiece. These alterations are related to machining parameters such as electrical discharge current (I), the type of modulation of applying voltage $(V)$, the time in which modulated voltage has been pulse-on time $\left(t_{\text {on }}\right)$ and pulse-off time $\left(t_{\text {off }}\right)$, machining time $(\tau)$, and the type of tool electrode and work-piece. ${ }^{11,12}$ Whereas changes in the chemical composition of surface influences its corrosion behavior, ${ }^{13}$ it is worthwhile to study the corrosion resistance of the workpiece made by EDM. Open circuit potential, potentiodynamic polarization, and electrochemical impedance spectrometry are the most common methods to study electrochemical corrosion. ${ }^{14,15}$ Due to the formation of protective layer on the workpiece surface during the corrosion tests, the electrochemical impedance spectrometry method is used.

In this study, the EDM method was carried out on stainless steel with a copper electrode. The stainless steel was used as workpiece due to its excellent mechanical properties ${ }^{16}$ high corrosion resistance in the corrosive medium, ${ }^{17}$ and the fact that it is the most applicable alloy ${ }^{18}$ for use in different industries e.g. medicine, ${ }^{6}$ military, ${ }^{19}$ aerospace ${ }^{20}$ and so on. A few studies have evaluated the 
corrosion behavior of the workpieces made by EDM showing the tool electrodes significantly affect the amount of workpiece corrosion. ${ }^{6,10,15,21-24}$

Yan et al. using weight loss test have shown that Al$\mathrm{Zn}-\mathrm{Mg}$ alloy machined by a copper electrode has high corrosion resistance. ${ }^{21}$ Tsai et al. have developed a sintered electrode tool made in $\mathrm{Cu}-\mathrm{Cr}(80-20 \%)$ composite to improve the uniform corrosion resistance of the AISI 1045 EDM surfaces. ${ }^{22}$ Sidoham et al. have determined the corrosion resistance of stainless steel using potentiometric test, which is machined by a graphite electrode in various EDM currents. ${ }^{23}$ They have indicated that by increasing the discharge current, the amount of the diffused carbon into the surface of the stainless steel, and as result the corrosion rate increases. Saravanan et al. used open circuit potential (OCP) and linear polarization measurements to show that the corrosion has occurred in EDMed $\mathrm{Al}$ alloys by the brass electrode due to the localized transfer of copper from of brass on the workpiece surface. ${ }^{24}$

In this study, we investigate the presence and diffusion of $\mathrm{Cu}$ on the stainless steel workpiece by changing the EDM parameters such as $I, t_{\mathrm{on}}, t_{\mathrm{off}}$ and $\tau$. Afterwards, the electrochemical corrosion rate of the workpiece is measured by the electrochemical impedance spectrometry (EIS) method. The Taguchi experimental design method is used in order to reduce the cost and time of the study. To keep the maintenance cost low and raising the efficiency of the industrial tools, we worked on the EDMed stainless steel using copper electrode and reporting the optimal values of the machining parameters.

\section{Material and Methods}

\section{1. Material}

- Stainless steel belt with a $5 \mathrm{~mm}$ thickness and copper rod with a $10 \mathrm{~mm}$ diameter, purchased from Tehran bazaar, Iran.

\section{2. Equipments and Software}

- Electric Discharge Machining, Model A6040L, Chmer Company, Taiwan.

- Quantometer, Model Foundry Master, Oxford Instruments Gmbh, Germany.

- X-ray Diffractometer (XRD) System, Model D8 Advance, Bruker Company, Germany.

- Optical Microscope, Model Olympus BX51M, Japan.

- Autolab Instrument, Model PGSTAT 30, Eco-Chemie Utrecht Company, Netherlands.

- Minitab Software, Version 16.4.2, Minitab Company, USA.

- Highscore Plus Software, Version 3.0.5, PANalytical B.V. Almelo Company, Netherlands.

- FRA Software, Version 4.9, Eco Chemie B.V Company, Netherlands.

\section{3. Material Preparation}

The selected workpiece material was stainless steel (SS) with the dimensions $30 \times 20 \times 5 \mathrm{~mm}^{3}$ and the electrode tool used in this work was made of a copper rod with a $10 \mathrm{~mm}$ diameter. The chemical composition of stainless steel and copper performed by foundry master instrument is reported in Table 1 and Table 2 respectively. The EDM machining operations was carried out with Chmer A6040L on workpieces. The paraffin oil was used as dielectric fluid. The raw and EDMed workpiece and electrode tool are shown in Figure 1. Experiments were conducted by control parameters variations such as $I, t_{\mathrm{on}}, t_{\mathrm{off}}, \tau$, and each one at five levels as shown in the Table 3 . The design of experiments was performed by using L 25 mixed levels of orthogonal arrays according to Taguchi method as listed in Table 4. a)
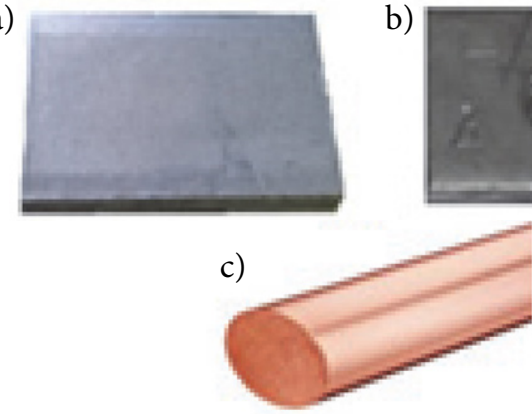

b)

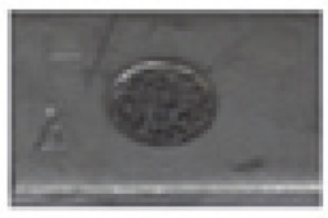

Figure 1. The image of (a) raw workpiece (b) EDMed workpiece (c) tool electrode.
Table 1. Chemical composition of raw workpiece (wt. \%).

\begin{tabular}{lccccccc}
\hline $\mathbf{F e}$ & $\mathbf{C}$ & $\mathbf{S i}$ & $\mathbf{M n}$ & $\mathbf{P}$ & $\mathbf{S}$ & $\mathbf{C r}$ & $\mathbf{M o}$ \\
70.2 & 0.0548 & 0.235 & 1.15 & 0.0325 & 0.005 & 19 & 0.22 \\
\hline $\mathbf{N i}$ & $\mathbf{A l}$ & $\mathbf{C o}$ & $\mathbf{C u}$ & $\mathbf{N b}$ & $\mathrm{Ti}$ & $\mathbf{V}$ & $\mathrm{W}$ \\
8.36 & 0.001 & 0.122 & 0.432 & 0.0185 & 0.0078 & 0.0616 & 0.02 \\
\hline
\end{tabular}

Table 2. Chemical composition of tool electrode (wt. \%).

\begin{tabular}{lccccccc}
\hline $\mathbf{C u}$ & $\mathbf{Z n}$ & $\mathbf{P b}$ & $\mathrm{Sn}$ & $\mathbf{P}$ & $\mathbf{M n}$ & $\mathbf{F e}$ & $\mathbf{N i}$ \\
99.7 & 0.1 & 0.005 & 0.005 & 0.003 & 0.0054 & 0.05 & 0.005 \\
\hline $\mathbf{S i}$ & $\mathbf{A l}$ & $\mathbf{C r}$ & $\mathbf{M g}$ & $\mathbf{S}$ & $\mathbf{A s}$ & $\mathbf{C o}$ & $\mathbf{A g}$ \\
0.0183 & 0.0095 & 0.001 & 0.002 & 0.0113 & 0.0041 & 0.023 & 0.0082 \\
\hline
\end{tabular}

Table 3. EDM design factors.

\begin{tabular}{lrrrrr}
\hline Design factor & \multicolumn{5}{c}{ Level } \\
& 1 & 2 & 3 & 4 & 5 \\
\hline $\boldsymbol{I}(\boldsymbol{A})$ & 5 & 10 & 15 & 20 & 25 \\
$\boldsymbol{t}_{\text {on }}(\boldsymbol{\mu s})$ & 50 & 75 & 100 & 125 & 150 \\
$\boldsymbol{t}_{\text {off }}(\boldsymbol{\mu s})$ & 5 & 10 & 15 & 20 & 25 \\
$\boldsymbol{\tau}($ min $)$ & 1 & 2 & 4 & 8 & 16 \\
\hline
\end{tabular}


Table 4. The results of experimental design by using L 25 orthogonal arrays.

\begin{tabular}{lcccc}
\hline Input parameters & & & & \\
$\mathbf{S . ~} \mathbf{N}$. & $\boldsymbol{I}(\boldsymbol{A})$ & $\boldsymbol{t}_{\text {on }}(\boldsymbol{\mu s})$ & $\boldsymbol{t}_{\text {off }}(\boldsymbol{\mu s})$ & $\boldsymbol{\tau}(\boldsymbol{m i n})$ \\
\hline 1 & 5 & 50 & 5 & 1 \\
2 & 5 & 75 & 10 & 2 \\
3 & 5 & 100 & 15 & 4 \\
4 & 5 & 125 & 20 & 8 \\
5 & 5 & 150 & 25 & 16 \\
6 & 10 & 50 & 10 & 4 \\
7 & 10 & 75 & 15 & 8 \\
8 & 10 & 100 & 20 & 16 \\
9 & 10 & 125 & 25 & 1 \\
10 & 10 & 150 & 5 & 2 \\
11 & 15 & 50 & 15 & 16 \\
12 & 15 & 75 & 20 & 1 \\
13 & 15 & 100 & 25 & 2 \\
14 & 15 & 125 & 5 & 4 \\
15 & 15 & 150 & 10 & 8 \\
16 & 20 & 50 & 20 & 2 \\
17 & 20 & 75 & 25 & 4 \\
18 & 20 & 100 & 5 & 8 \\
19 & 20 & 125 & 10 & 6 \\
20 & 20 & 150 & 15 & 1 \\
21 & 25 & 50 & 25 & 8 \\
22 & 25 & 75 & 5 & 16 \\
23 & 25 & 100 & 10 & 1 \\
24 & 25 & 125 & 15 & 2 \\
25 & 25 & 150 & 20 & 4 \\
\hline & & & & \\
\hline 5. & 50 & &
\end{tabular}

S. N. The number of EDMed workpieces.

\section{4. Methods}

\section{4. 1. Quantometer Analysis}

The EDM process induces changes in the chemical composition of the surface of the workpieces. Therefore, the chemical elements of these workpieces are performed by foundry master instrument (the quantometer analysis) and the results are presented in Table 5.

\section{4. 2. Optical Microscopy}

The micrograph observation is performed by an Olympus BX51M optical microscope (OM) in a fixed magnification of 1000 .

\section{4. 3. XRD Analysis}

The phases on the workpiece's surface have been studied via XRD analysis. Analyses were performed by $\mathrm{X}$-ray diffraction (XRD) (Bruker D8 advance) at a wavelength of $0.15406 \mathrm{~nm}$ using the copper kal radiation. Diffraction patterns were recorded at $45 \mathrm{kV}$ and $48 \mathrm{~mA}$ in $1 \%$ setectors movement speed, intensity was measured in $2 \theta=0.02^{\circ}$. Spectra were collected at $2 \theta$ values between $20^{\circ}-80^{\circ}$. X'Pert High Score Plus, V3.0.5 software were used to analyze the obtained data.

\section{4. 4. Electrochemical Corrosion Test}

The electrochemical behavior of EDMed workpieces was studied with the electrochemical impedance spectroscopy (EIS) using AUTOLAB model PGSTAT 30 equipped with a frequency response analyzer (FRA) software. The three electrode cell was used for the electrochemical measurements. We used workpiece with an exposed area of $0.65 \mathrm{~cm}^{2}$ as the working electrode. A saturated calomel

Table 5. Chemical composition (wt. \%) of workpiece after EDM.

\begin{tabular}{|c|c|c|c|c|c|c|c|c|c|c|c|c|c|c|c|c|}
\hline S.N. & $\mathrm{Fe}$ & $\mathrm{C}$ & $\mathrm{Si}$ & Mn & $\mathbf{P}$ & $\mathbf{S}$ & $\mathrm{Cr}$ & Mo & $\mathrm{Ni}$ & Al & Co & $\mathrm{Cu}$ & $\mathbf{N b}$ & $\mathrm{Ti}$ & V & $W$ \\
\hline 1 & 69.8 & 1.06 & 0.207 & 1.11 & 0.0204 & 0.005 & 18.3 & 0.198 & 8.51 & 0.001 & 0.130 & 0.489 & 0.0114 & 0.0063 & 0.0558 & 0.02 \\
\hline 2 & 69.8 & 1.10 & 0.199 & 1.12 & 0.0067 & 0.005 & 18.2 & 0.206 & 8.60 & 0.001 & 0.118 & 0.474 & 0.0129 & 0.0064 & 0.0611 & 0.0278 \\
\hline 3 & 69.7 & 1.23 & 0.195 & 1.10 & 0.0072 & 0.005 & 18.0 & 0.204 & 8.71 & 0.001 & 0.117 & 0.457 & 0.0134 & 0.0059 & 0.0612 & 0.0230 \\
\hline 4 & 69.4 & 1.23 & 0.226 & 1.14 & 0.003 & 0.0050 & 18.4 & 0.191 & 8.47 & 0.0015 & 0.115 & 0.432 & 0.0088 & 0.0087 & 0.0611 & 0.124 \\
\hline 5 & 69.1 & 1.49 & 0.191 & 1.16 & 0.003 & 0.005 & 18.2 & 0.185 & 8.74 & 0.001 & 0.123 & 0.448 & 0.0093 & 0.0074 & 0.0649 & 0.144 \\
\hline 6 & 69.5 & 0.808 & 0.217 & 1.14 & 0.003 & 0.005 & 18.7 & 0.191 & 8.49 & 0.0013 & 0.12 & 0.561 & 0.0082 & 0.0079 & 0.0609 & 0.128 \\
\hline 7 & 69.1 & 1.41 & 0.210 & 1.13 & 0.003 & 0.005 & 18.3 & 0.183 & 8.59 & 0.001 & 0.112 & 0.638 & 0.0075 & 0.0071 & 0.0596 & 0.120 \\
\hline 9 & 69.5 & 0.983 & 0.184 & 1.16 & 0.0041 & 0.005 & 15.5 & 0.190 & 8.64 & 0.001 & 0.121 & 0.492 & 0.0099 & 0.0059 & 0.0646 & 0.0389 \\
\hline 10 & 69.6 & 0.909 & 0.169 & 1.15 & 0.003 & 0.005 & 18.4 & 0.189 & 8.82 & 0.001 & 0.119 & 0.453 & 0.0107 & 0.0053 & 0.0651 & 0.0395 \\
\hline 12 & 69.5 & 1.04 & 0.178 & 1.14 & 0.0035 & 0.005 & 18.2 & 0.190 & 8.61 & 0.001 & 0.126 & 0.72 & 0.0109 & 0.005 & 0.0645 & 0.0245 \\
\hline 13 & 69.1 & 1.45 & 0.183 & 1.16 & 0.003 & 0.005 & 18.3 & 0.182 & 8.62 & 0.001 & 0.123 & 0.614 & 0.0087 & 0.006 & 0.0634 & 0.118 \\
\hline 14 & 69.8 & 0.638 & 0.213 & 1.16 & 0.003 & 0.005 & 18.6 & 0.187 & 8.55 & 0.001 & 0.0988 & 0.486 & 0.0082 & 0.0072 & 0.0624 & 0.0933 \\
\hline 15 & 69.4 & 1.28 & 0.190 & 1.119 & 0.003 & 0.005 & 18.1 & 0.183 & 8.58 & 0.001 & 0.124 & 0.528 & 0.0086 & 0.0073 & 0.0662 & 0.168 \\
\hline 16 & 69.6 & 0.562 & 0.236 & 1.14 & 0.003 & 0.005 & 18.8 & 0.196 & 8.45 & 0.001 & 0.105 & 0.629 & 0.0098 & 0.0091 & 0.0611 & 0.125 \\
\hline 17 & 69.2 & 1.44 & 0.225 & 1.11 & 0.003 & 0.005 & 18 & 0.196 & 8.61 & 0.0015 & 0.126 & 0.771 & 0.0125 & 0.0089 & 0.0601 & 0.143 \\
\hline 18 & 67.2 & 2.6 & 0.212 & 1.10 & 0.003 & 0.005 & 17.1 & 0.190 & 8.52 & 0.0019 & 0.12 & 0.62 & 0.012 & 0.0088 & 0.0584 & 0.171 \\
\hline 20 & 69.3 & 1.37 & 0.175 & 1.15 & 0.003 & 0.005 & 18.1 & 0.186 & 8.81 & 0.001 & 0.101 & 0.594 & 0.0112 & 0.0054 & 0.0646 & 0.0582 \\
\hline 23 & 68.9 & 1.68 & 0.195 & 1.12 & 0.003 & 0.005 & 18.1 & 0.183 & 8.65 & 0.001 & 0.0997 & 0.757 & 0.0083 & 0.007 & 0.0597 & 0.111 \\
\hline 24 & 67.7 & 2.6 & 0.165 & 1.11 & 0.003 & 0.005 & 17.3 & 0.192 & 8.87 & 0.001 & 0.117 & 0.833 & 0.0109 & 0.0059 & 0.0676 & 0.0913 \\
\hline 25 & 67.1 & 2.6 & 0.201 & 1.11 & 0.003 & 0.005 & 17 & 0.179 & 8.72 & 0.0018 & 0.122 & 0.763 & 0.0094 & 0.008 & 0.0572 & 0.178 \\
\hline
\end{tabular}


electrode (SCE) and platinum tip electrode were used as the reference and the counter, respectively. Every sample (S.N) from Table 4 was subject to measure three replication using fresh $3.5 \mathrm{wt}$. \% $\mathrm{NaCl}$ solutions without aeration, at room temperature. The impedance studies were performed at a frequency range from $0.01 \mathrm{~Hz}$ to $1 \mathrm{MHz}$ sine wave with $5 \mathrm{mV}$ perturbation amplitude. All of the measurements were done in potentiostatic mode at room temperature. The EIS data are calculated by Nyquist plots. The boukamp equivalent circuit utility as a part of FRA program are the most reliable simulated electrical circuit based on the impedance data.

\section{Results and Discussion}

\section{1. Microstructural Changes}

Thermal energy generated by EDM leads to chenges in workpiece surface. The EDMed workpiece surface phases, identified by X-ray diffraction (see Figure 2), revealed several different phases such as copper $\left(\mathrm{Cu}_{4}\right)$ with cubic crystal structure, carbon $\left(\mathrm{C}_{16}\right)$ with cubic crystal structure, and carbides ( $\mathrm{FeC}$ with hexagonal crystal structure, $\mathrm{Cr}_{3} \mathrm{C}_{2}$ with orthorhombic crystal structure). Lattice parameters of these phases are calculated using_X'Pert High Score Plus software and the results were reported in Table 6 , and as an example the diffractograms of workpiece-16 is depicted in Figure 3.

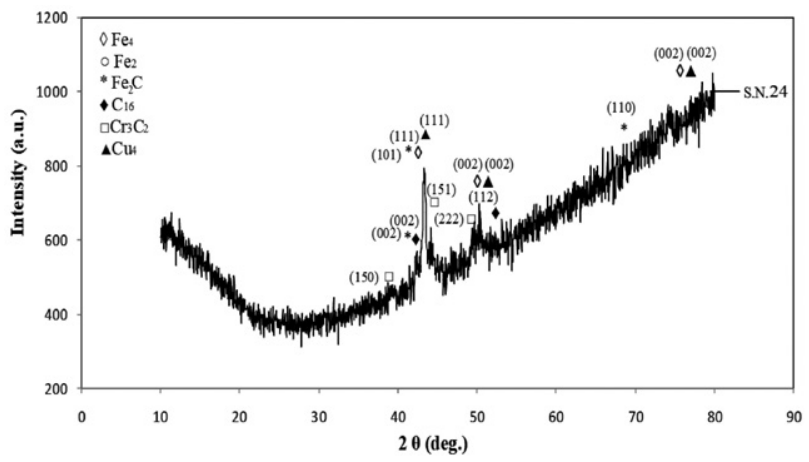

Figure 2. X-ray spectrum of the surface workpiece-24.

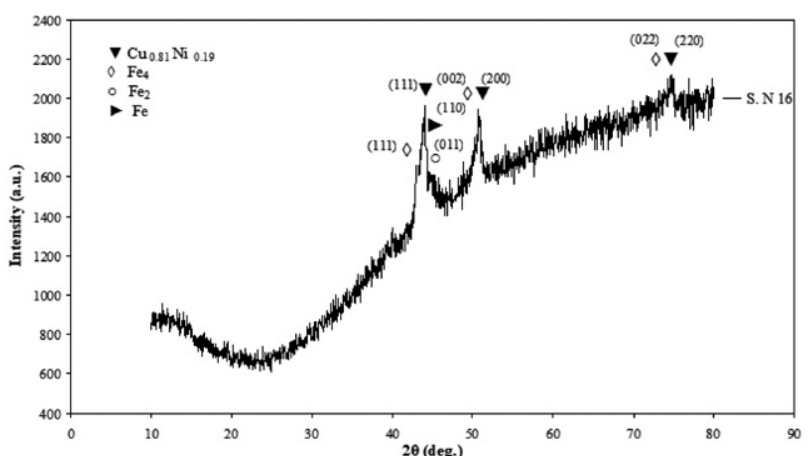

Figure 3. X-ray spectrum of the surface workpiece-16.
During the spark ignition in the EDM process, the copper is melted away from the tool electrode. Therefore, the copper particles diffuse into the workpiece surface and as a result of their combination with the Nickel particles, $\mathrm{Cu}_{\mathrm{x}} \mathrm{Ni}_{\mathrm{y}}$ crystals were formed. It should be mentioned that copper and Nickel have the same lattice parameters. The lattice parameters of these phases were calculated using the X'Pert High Score Plus software and the results are reported in Table 7.

Table 6. Lattice parameters of workpiece surface phases, workpiece-24.

\begin{tabular}{|c|c|}
\hline Chemical formula & Lattice parameters \\
\hline $\mathrm{Fe}_{4}$ & $\begin{array}{c}\text { Cubic } \\
a=b=c=0.362 \mathrm{~nm} \\
\alpha=\beta=\gamma=90^{\circ}\end{array}$ \\
\hline $\mathrm{Fe}_{2}$ & $\begin{array}{c}\text { Cubic } \\
a=b=c=0.362 \mathrm{~nm} \\
\alpha=\beta=\gamma=90^{\circ}\end{array}$ \\
\hline $\mathrm{Cu}_{4}$ & $\begin{array}{c}\text { Cubic } \\
a=b=c=0.362 \mathrm{~nm} \\
\alpha=\beta=\gamma=90^{\circ}\end{array}$ \\
\hline $\mathrm{Fe}_{2} \mathrm{C}$ & $\begin{array}{c}\text { Hexagonal } \\
a=b=c=0.275 \mathrm{~nm} \\
\alpha=\beta=90, \gamma=120^{\circ}\end{array}$ \\
\hline $\mathrm{Cr}_{3} \mathrm{C}_{2}$ & $\begin{array}{c}\text { Orthorhombic } \\
\begin{array}{c}a=b=c=0.701 \mathrm{~nm} \\
\alpha=\beta=\gamma=90^{\circ}\end{array}\end{array}$ \\
\hline $\mathrm{C}_{16}$ & $\begin{array}{c}\text { Cubic } \\
a=b=c=0.429 \mathrm{~nm} \\
\alpha=\beta=\gamma=90^{\circ}\end{array}$ \\
\hline
\end{tabular}

Table 7. Lattice parameters of workpiece surface phases, workpiece-16.

\begin{tabular}{|c|c|}
\hline Chemical formula & Lattice parameters \\
\hline $\mathrm{Fe}_{4}$ & $\begin{array}{c}\text { Cubic } \\
a=b=c=0.362 \mathrm{~nm} \\
\alpha=\beta=\gamma=90^{\circ}\end{array}$ \\
\hline $\mathrm{Fe}_{2}$ & $\begin{array}{c}\text { Cubic } \\
a=b=c=0.362 \mathrm{~nm} \\
\alpha=\beta=\gamma=90^{\circ}\end{array}$ \\
\hline $\mathrm{Fe}$ & $\begin{array}{c}\text { Cubic } \\
a=b=c=0.2853 \mathrm{~nm} \\
\alpha=\beta=\gamma=90^{\circ}\end{array}$ \\
\hline $\mathrm{Cu}_{0.8} \mathrm{Ni}_{0.19}$ & $\begin{array}{c}\text { Cubic } \\
a=b=c=0.35934 \mathrm{~nm} \\
\alpha=\beta=\gamma=90^{\circ}\end{array}$ \\
\hline
\end{tabular}

As evident from Figures 2 and 3, the sources of carbon and copper particles penetrating on the workpiece surface are from the dielectric solution and copper elec- 
trode, respectively. The diffused carbon particles are combined with the workpiece material to form a carbide zone. Our results are in line with Chundru, ${ }^{25}$ Torres ${ }^{26}$ Sidhom, ${ }^{23}$ and Cusanelli findings. ${ }^{27}$ The mechanism of copper diffusion in the machining process is discussed below.

\section{2. Effect of Copper Diffusion on EDMed Surface}

The schematic of the mechanism of copper diffusion in the machining process is shown in Figures 4.

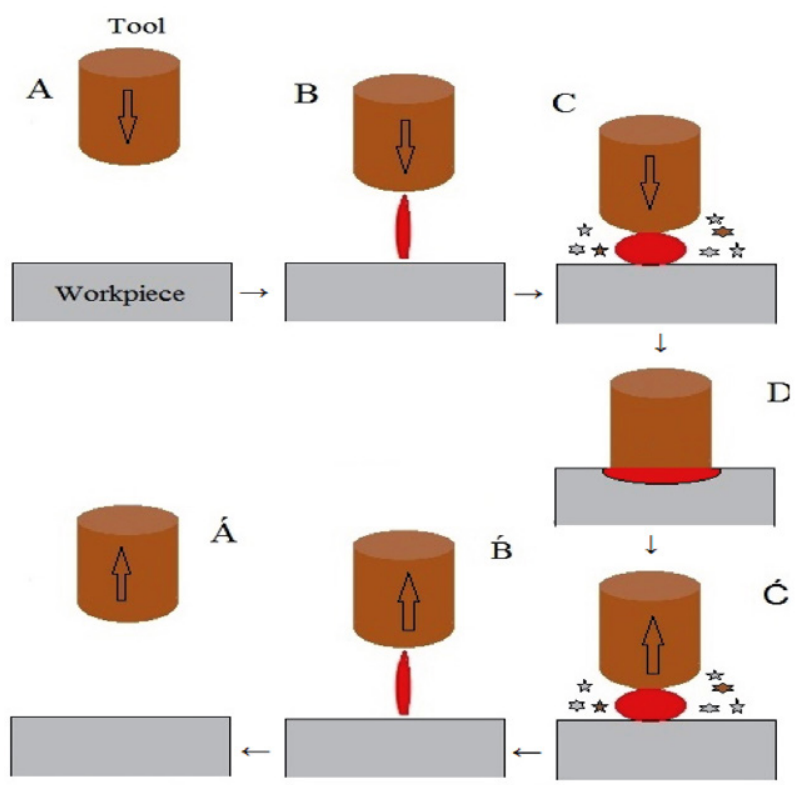

Figure 4. Schematic of the copper diffusion mechanism during EDM.

During step A, the tool electrode is coming close to the workpiece surface. Then, in step B, the discharge current is set between the tool electrode and workpiece by deionizing the dielectric fluid and the creation of the plasma channel. When the discharge current is increased, the thermal energy produced by sparks can warm up the electrodes. Therefore, it causes the debris melted materials to be sputtered into the dielectric liquid. Some of these particles do not exit the dielectric solution and, consequently, they fell on the workpiece (or tool electrode) surface (step C). Finally, as the tool electrode is getting closer to the workpiece its surface connects to the workpiece (step D). In this case, passing electric current produces heat due to joule effect. As a result, the tool electrode materials diffuse onto the surface of the substrate. During the next step the tool electrode is removed from the workpiece surface, and as a result of the distance the spark width and its impact are reduced. Flushing of dielectric liquid leads to a decrease in the temperature, such that there is no spark in step Á. Ultimately, the whole process would be repeated again. It is evident that step D can be introduced as the main stage in which the $\mathrm{Cu}$ diffuses onto the workpiece. It should be noted that the copper diffusion also occurs in other stages of the EDM process; but the amount is not comparable with step $\mathrm{D}$. The linear movement of the velocity of the tool electrode axle ${ }^{28}$ will be constant during the whole steps from A to Á. Therefore, the amount of copper diffusion can be described as a function of pulse-on time.

\section{3. Effect of Discharge Current on Copper Diffusion}

The results of the quantometer analysis show the different amounts of copper and carbon on the workpiece surface (Table 5). To investigate the overall effects of the copper and carbon amounts with different discharge currents, their mean values were calculated are reported in Table 8.

Table 8. The mean values of copper and carbon of Stainless Steel.

\begin{tabular}{ccc}
\hline $\begin{array}{c}\text { Discharge Current } \\
\text { (A) }\end{array}$ & $\begin{array}{c}\text { Mean copper } \\
\text { (wt. \%) }\end{array}$ & $\begin{array}{c}\text { Mean carbon } \\
\text { (wt. \%) }\end{array}$ \\
\hline 5 & 0.46 & 1.22 \\
10 & 0.54 & 1.03 \\
15 & 0.59 & 1.10 \\
20 & 0.66 & 1.49 \\
25 & 0.78 & 2.29 \\
\hline
\end{tabular}

The effect of current on the mean values of the diffusion of $\mathrm{Cu}$ was already shown in Figure 5. The diffusion of $\mathrm{Cu}$ on stainless steel surface was increased by raising the current values. This can be attributed to the lower melting point of $\mathrm{Cu}$ rather than the stainless steel and the fact that EDM develops a high-temperature zone on the surface ${ }^{29}$. For this reason the incremental diffusion is slow.

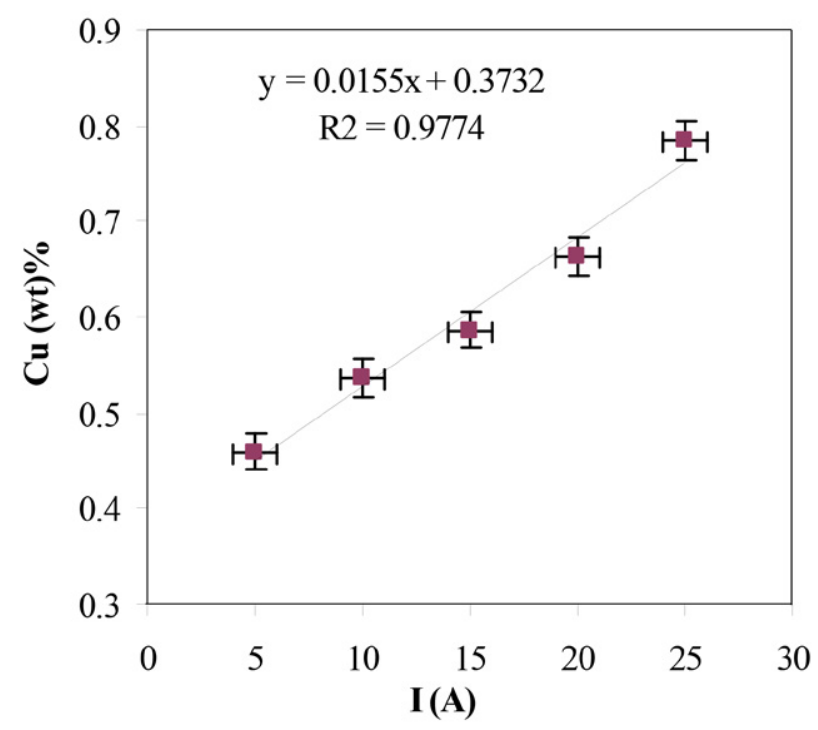

Figure 5. Effect of I on diffusion mean of copper in workpiece. 
The change in the weight percent of other elements as well as for $\mathrm{Cu}$ can occur in the machining process. Table 8 shows that by increasing discharge current the weight percent (wt. \%) of carbon increased from $0.0548 \%$ (without EDM) to $2.29 \%$ ( $I=25 \mathrm{~A})$. This is related to the diffusion of the carbon from the dielectric solution into the workpiece surface when the flashing occurs. This result is in agreement with the Elaiyarasan, ${ }^{30}$ Torres, ${ }^{26} \mathrm{Kumar}^{31}$ and $\mathrm{John}^{32}$. The-results from quantometer analysis agreed to ones obtained by XRD analysis.

\section{4. Effect of Pulse-on time and Pulse-off time on Copper Diffusion}

The diffusion of $\mathrm{Cu}$ on the surface of workpiece in high $(125,150 \mu \mathrm{s})$ and low $(50,70,100 \mu \mathrm{s})$ values of $t_{\text {on }} \mathrm{vs}$. discharge current were sketched in Figure 6. The findings show that the amount of diffusion of copper on the surface of the workpiece was high when $t_{\text {on }}$ was low. However, this phenomenon was amplified by increasing the discharge current.

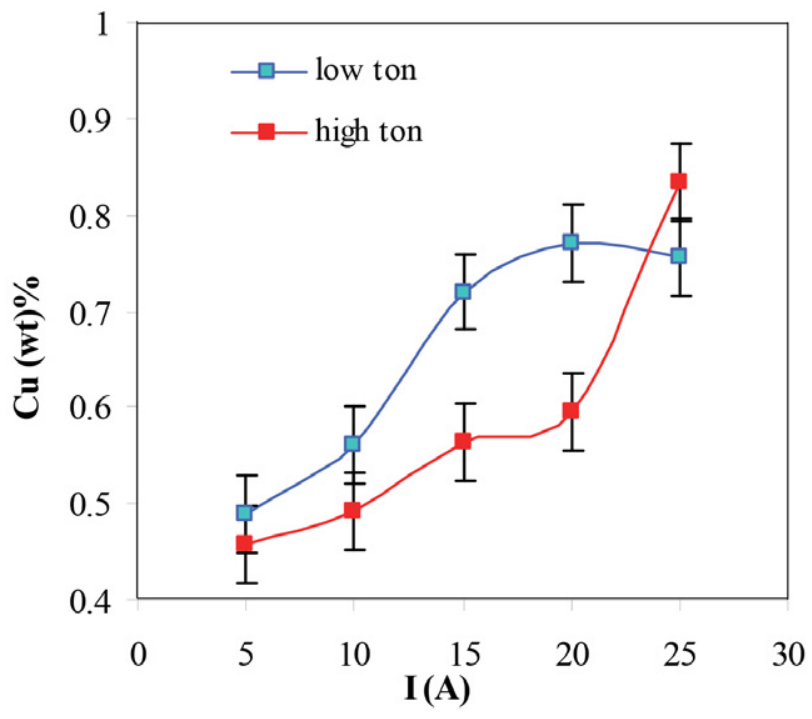

Figure 6. Diagram of diffused copper wt. \% vs. discharge current at high and low $t_{\mathrm{on}}$.

In the machining process, the greatest value of copper on the workpiece surface was observed at $t_{\text {off }}=15$ and $20 \mu$ s. Figure 7 illustrates the copper values vs. $t_{\text {off. }}$.

The results obtained from the optical microscopy show that the microscopic images of machined workpiece at the high discharge current, high $t_{\text {on }}$ and low $t_{\text {off }}$ have long and branched cracks on the surface. The presence of crack and micro-crack on the surface maybe attributed to the retention of the dielectric fluid during the cooling of the surface ${ }^{33,34}$. Ultimately, Stress Corrosion Cracking (SCC) in aggressive environments occurs in this case. Figure 8-a, shows the microscopic images of the workpiece- 24 with high values of discharge current and $t_{\mathrm{on}}$.

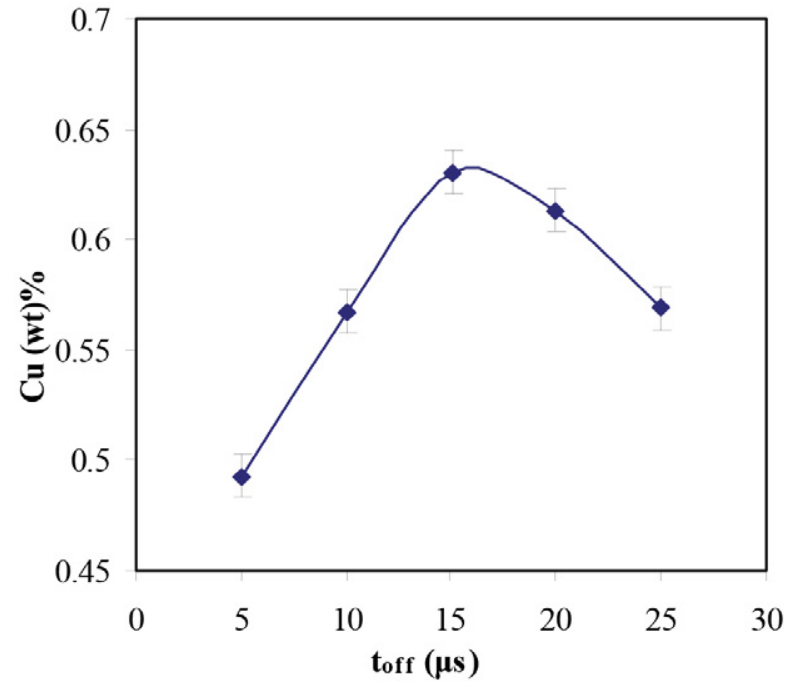

Figure 7. Diagram of diffused copper wt. \% vs. $t_{\text {off }}$.
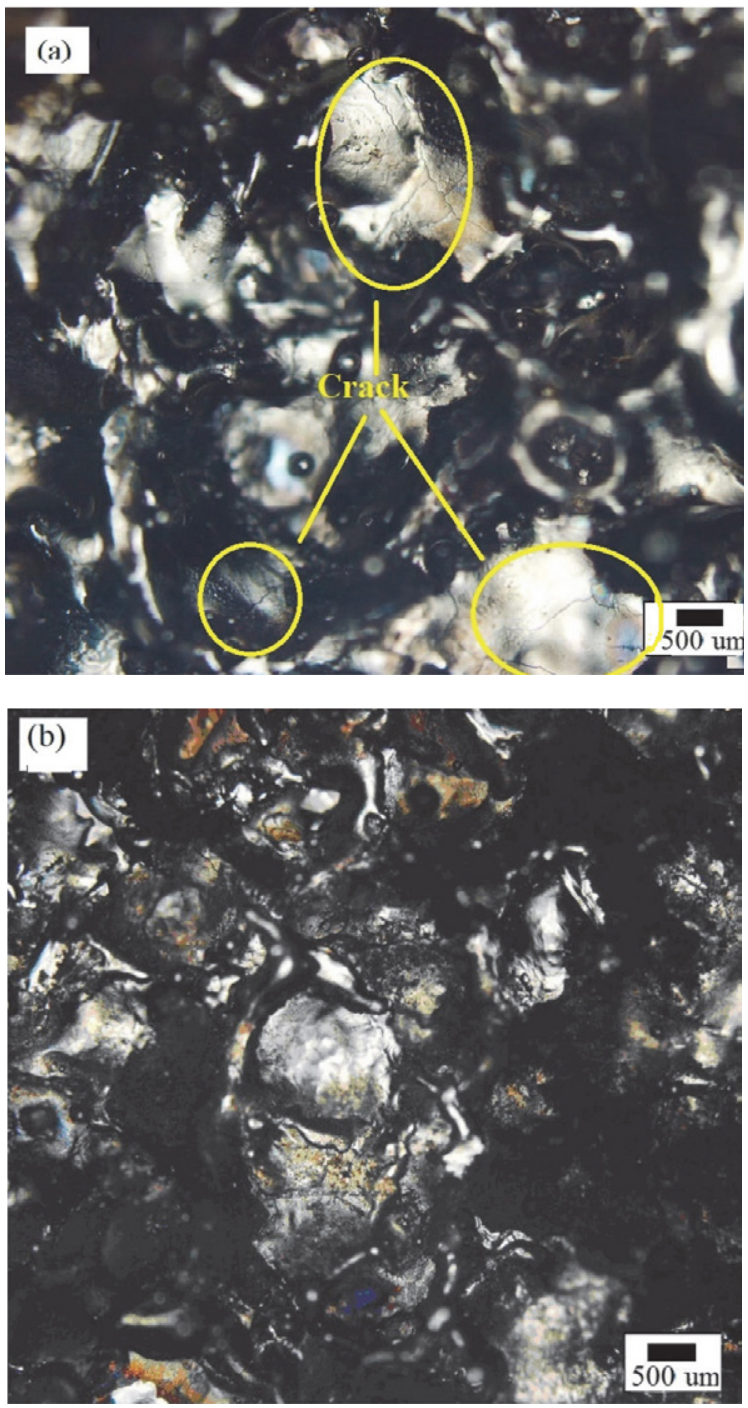

Figure 8. Optical micrograph of stainless steel EDMed through copper electrode at high discharge current and (a) high $t_{\mathrm{on}}$, (b) low $t_{\text {on }}$ by magnification of 1000 . 
As shown in workpiece-16, there is a suitable ratio of $t_{\text {on }} / t_{\text {off }}$ (Figure 8-b). The highest amount of Cu diffusion and the surface without any cracks or micro-cracks are observed under the condition of higher amounts of discharge current, lower $t_{\mathrm{on}}$, higher $t_{\mathrm{off}}$ with much shorter $\tau$. The value of diffused $\mathrm{Cu}$ is high (0.629\%) as reported in Table 5. These conditions prevent the workpiece from formation of any cracks, micro-cracks or branching.

\section{5. Electrochemical Corrosion}

The electrochemical impedance spectroscopy diagram (Nyquist plot) for workpiece-16 is presented in Figure 9.

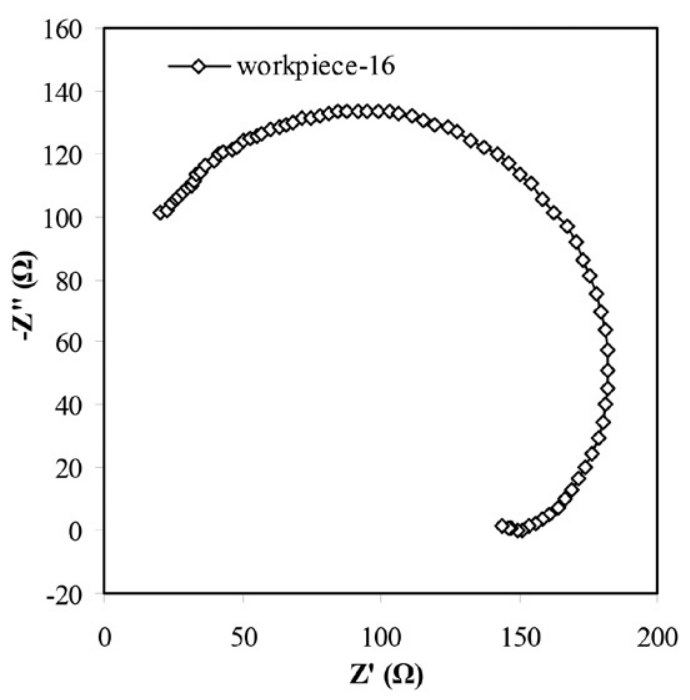

Figure 9. Nyquist plot of EIS results for workpiece 16.

To investigate the effect of copper on the corrosion resistance of Stainless Steel the mean values of the diffused copper (obtained by quantometer analysis) and the mean values of the corrosion resistance $\left(R_{\mathrm{CT}}\right)$ as well as electrical double layer capacitance ( $C_{\mathrm{EDL}}$ ) (obtained by EIS analysis) in various currents are presented in Table 9.

Table 9. The mean values of the diffused copper, $R_{\mathrm{CT}}$ and $C_{\mathrm{EDL}}$ in various discharge currents.

\begin{tabular}{cccc}
\hline $\begin{array}{c}\text { Discharge } \\
\text { Current (A) }\end{array}$ & $\begin{array}{c}\text { Mean copper } \\
(\text { wt. \%) }\end{array}$ & $\begin{array}{c}\text { Mean } \boldsymbol{R}_{\mathrm{CT}} \\
(\boldsymbol{\Omega})\end{array}$ & $\begin{array}{c}\text { Mean } C_{\mathrm{EDL}} \\
(\boldsymbol{\mu F})\end{array}$ \\
\hline 5 & 0.46 & 385 & 7.6 \\
10 & 0.536 & 453 & 12 \\
15 & 0.587 & 495 & 14 \\
20 & 0.66 & 590 & 21 \\
25 & 0.78 & 456 & 18 \\
\hline
\end{tabular}

The resulting effects of various discharge currents on the mean values of the diffused $\mathrm{Cu}$ and corrosion resistance (Table 9) of stainless steel are showed in Figure 10. It shows that by increasing the discharge current $(I=20 \mathrm{~A})$ the corrosion resistance also rises $\left(R_{\mathrm{CT}}=590 \Omega\right)$. In this situation, the XRD analysis shows that the stable phase of $\mathrm{Cu}_{0.81} \mathrm{Ni}_{0.19}$ is formed and also optical microscopy show no cracks or micro-cracks (Figure 8-b). However, when the discharge current is too high $(I=25 \mathrm{~A})$, the $R_{\mathrm{CT}}$ significantly is reduced $\left(R_{\mathrm{CT}}=456 \Omega\right)$ and the cracks are developed on the workpiece (Figure 8-a). These observations are consistent with the finding of Sidoham et $\mathrm{al}^{23}$.

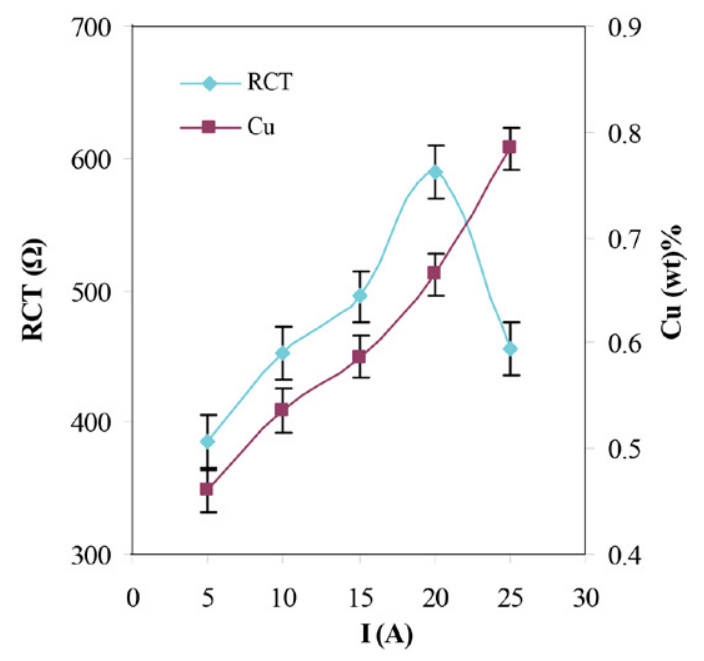

Figure10. Effect of the discharge current on the mean value of $R_{\mathrm{CT}}$ and $\mathrm{Cu}(\mathrm{wt} . \%)$.

As Figure 10 shows, the $\mathrm{Cu}$ diffusion on the surface grows with the rising discharge current, and subsequently the corrosion rate is decreased. Many researchers ${ }^{35-39}$ have reported that $\mathrm{Cu}$ diffusion plays an important role in corrosion resistance. Copper maybe stable either as metallic copper, soluble $\mathrm{CuCl}_{2}^{-}$complex, insoluble $\mathrm{CuCl}$ salt film or as $\mathrm{Cu}^{2+}$ ions on the workpiece surface in corrosive environment by following mechanisms:

Ionization of $\mathrm{Cu}$ atom produces $\mathrm{Cu}^{2+}$ ions according to Eq. $1^{37,38}$.

$$
\mathrm{Cu}^{2+}+2 \mathrm{e}^{-} \leftrightarrows \mathrm{Cu} \quad \mathrm{E}_{0}=+0.337 \mathrm{~V}
$$

The anodic reaction of $\mathrm{Cu}$ by the production of $\mathrm{CuCl}$ salt and $\mathrm{CuCl}_{2}{ }^{-}$complex occurs in chloride. The reaction is Eq. 2 and Eq. $3^{37,40}$.

$$
\begin{array}{ll}
\mathrm{CuCl}^{+} \mathrm{e}^{-} \leftrightarrows \mathrm{Cu}+\mathrm{Cl}^{-} & \mathrm{E}_{0}=+0.137 \mathrm{~V} \\
\mathrm{CuCl}_{2}^{-}+\mathrm{e}^{-} \leftrightarrows \mathrm{Cu}+2 \mathrm{Cl}^{-} & \mathrm{E}_{0}=+0.208 \mathrm{~V}
\end{array}
$$

The protective layer protects the stainless steel from corrosion. The corrosion resistance effect is related to the creation of an electrical double layer of metal/ electrolyte in this case. Whereas the protection of the copper chloride layer is severely unstable, during the EDM process the workpiece is corroded electrochemically by pitting corro- 
sion mechanism. In contrast, in high $t_{\text {on }}$, workpiece doesn't have sufficient time for cooling; this situation provides the conditions for growing cracks on the surface (Figure 8-a). At high values of both discharge current and $t_{\text {on }}$ (workpiece-24) the branched long cracks can be formed and the corrosion resistance of workpiece dramatically falls $\left(R_{\mathrm{CT}}\right.$ $=456 \Omega$ ). The results of X-ray at very high discharge current and high $t_{\mathrm{on}}$ (Figure 2) indicate the presence of heterogeneous phases such as iron-phase with cubic structure, iron-carbide phase with hexagonal structure and chromium carbide with orthorhombic structure on the workpiece surface. Variation in workpiece lattice structure (cubic, hexagonal and orthorhombic) and different thermodynamic stability lead to the cracking of the workpiece and increase in the corrosion rates. The order of decreasing enthalpy formation of this workpiece is given in Table 10.

Table 10. Formation enthalpies of crystal observed in workpieces-16 and 24.

\begin{tabular}{cccc}
\hline S.N & Component & $\Delta \boldsymbol{H}_{\boldsymbol{f}}, \mathbf{K J ~ m o l}^{\mathbf{- 1}}$ & Reference \\
\hline 24 & $\mathrm{Fe}$ & 13.79 & 41 \\
& $\mathrm{Fe}_{2} \mathrm{C}$ & 2.57 & 42 \\
& $\mathrm{Cr}_{3} \mathrm{C}_{2}$ & -111.95 & 43 \\
\hline 16 & $\mathrm{Fe}$ & 13.79 & 41 \\
& $\mathrm{CuNi}$ & 3.7 & 44 \\
\hline
\end{tabular}

The EDMed workpiece with a high discharge current and $t_{\text {off }}$ and low $t_{\text {on }}$ and $\tau$ (workpiece-16) cools slowly enough to avoid cracks formation (Figure 8-b). XRD analysis (Figure 3) show that in this workpiece all the phases grow up in the same cubic crystal lattice (Table 7), which have the low formation enthalpy and subsequently are stable (Table 10). Under these conditions, the $R_{\mathrm{CT}}$ increases dramatically $\left(R_{\mathrm{CT}}=590 \Omega\right)$.

From the workpiece-16 results, it can be found that the corrosion rate is very low. In this workpiece, high discharge current and large amount of heat is developed on the surface. Also, it can be seen from Figure 8-b that the metal is allowed to cool sufficiently and therefore the cracks are not formed because the value of $t_{\text {on }}$ is low. The quantometer analysis results (Table 4) show that during the machining process, the values of the diffused $\mathrm{Cu}$ and $\mathrm{C}$ on the workpiece's surface are 0.629 and 0.5072 respectively. In workpiece-16 the diffused $\mathrm{Cu}$ is higher and the diffused carbon is lower than the other workpieces. This leads to a good corrosion resistance properties. Note that the amount of $C_{\mathrm{EDL}}$ of workpiece-16 $\left(C_{\mathrm{EDL}}=21 \mu \mathrm{F}\right)$ is the highest value among other workpieces as shown in Table 9.

\section{Conclusions}

The corrosion resistance of the stainless steel is an important issue because of its application in many indus- tries. The EDM technique is one of the methods for production and manufacturing of industrial Stainless Steel. In EDM technique a locally rising temperature causes a change in the chemical composition and diffusion of the tool electrode onto the surface of workpiece. The electrochemical properties of the stainless steel are also changed due to the variation in EDM parameters. The results show that by increasing discharge current and $t_{\mathrm{on}}$, the copper of tool electrode and carbon of dielectric liquid are diffused constituting some phases such as $\mathrm{Fe}_{2} \mathrm{C}, \mathrm{Cr}_{3} \mathrm{C}_{2}$, and $\mathrm{CuNi}$ onto the surface of workpiece. Besides, at higher values of both discharge current and $t_{\text {on }} / t_{\text {off }}$ ratio, the micro-cracks propagate. By increasing discharge current with an optimal level of $t_{\mathrm{on}} / t_{\mathrm{off}}$ ratio, the amount of diffusion of $\mathrm{Cu}$ onto the surface rises and then the electrochemical corrosion is reduced. Workpiece under optimal conditions $(I=$ $20 \mathrm{~A}, t_{\mathrm{on}}=50 \mu \mathrm{s}, t_{\mathrm{off}}=20 \mu \mathrm{s}, \tau=2 \mathrm{~min}$ ), shows high corrosion resistance due to the formation of the copper-nickel phase with no cracks or micro-cracks on its surface.

\section{References}

1. R. P. Zeilmann, T. Vacaro, F. M. Zanotto and M. Czarnobay, Matéria (Rio de Janeiro) 2013, 18, 1541-1548.

DOI:10.1590/S1517-70762013000400014

2. T. Ni, Q. Liu, Y. Wang, Z. Chen and D. Jiang, Coatings 2021, 11, 322. DOI:10.3390/coatings11030322

3. L. Tang and Y. Guo, The international Journal of advanced manufacturing Technology 2014, 70, 1369-1376.

DOI:10.1007/s00170-013-5380-4

4. D. N. Mishra, A. Bhatia and V. Rana, The International Journal of Engineering and Science (IJES) 2014, 3, 24-35.

5. S. Arooj, M. Shah, S. Sadiq, S. H. I. Jaffery and S. Khushnood, Arabian Journal for Science and Engineering 2014, 39, 41874199. DOI:10.1016/j.dental.2010.08.001

6. A. Ntasi, W. D. Mueller, G. Eliades and S. Zinelis, dental materials 2010, 26, e237-e245. DOI:10.1016/j.dental.2010.08.001

7. Z. Karastojković, Z. Janjušević, in: J. Mickovski (ed.), Hardness and structure changes at surface in electrical discharge machined steel C 3840: Proceedings of $3^{\text {rd }}$ Balkan Conference on Metallurgy BMC-2003, Ohrid, Macedonia, 2003, Ohrid, Macedonia, pp. 129-133.

8. S. Gopalakannan and T. Senthilvelan, Journal of Minerals and Materials Characterization and Engineering 2012, 11, 685. DOI:10.4236/jmmce.2012.117053

9. A. K. Tiwari, Int. Journal of Engineering Research and Applications 2014, 4, 91-95.

10. X. Yan, S. Zhang, J. Li and G. Wang: ASME 2015 International Manufacturing Science and Engineering Conference, American Society of Mechanical Engineers Digital Collection, 2015. DOI:10.1115/MSEC2015-9261

11. D. Thesiya, J. Dave and A. Rajurkar, Advances in Manufacturing Science and Technology 2014, 38.

DOI:10.2478/amst-2014-0023

12. M. Patel Gowdru Chandrashekarappa, S. Kumar, D. Y. 
Pimenov and K. Giasin, Metals 2021, 11, 419. DOI:10.3390/met11030419

13. A. Pardo, M. Merino, A. Coy, F. Viejo, R. Arrabal and E. Matykina, Corrosion Science 2008, 50, 1796-1806.

DOI:10.1016/j.corsci.2008.04.005

14. O. M. Ama, Book Nanostructured Metal-Oxide Electrode Materials for Water Purification: Fabrication, Electrochemistry and Applications, Springer Nature, 2020. DOI:10.1016/j.teac.2014.07.001

15. J. G. G. Manjunatha, Journal of food and drug analysis 2018, 26, 292-299. DOI:10.1016/j.jfda.2017.05.002

16. Y. Guo, J. Hu, J. Li, L. Jiang, T. Liu and Y. Wu, Materials 2014, 7, 6604-6619. DOI:10.3390/ma7096604

17. C. Loto, O. Fayomi and R. Loto, International Journal of Electrochemical Science 2012, 7, 3787-3797. DOI:10.1007/s00170-012-4156-6

18. K. H. Lo, C. H. Shek and J. Lai, Materials Science and Engineering: R: Reports 2009, 65, 39-104.

DOI:10.1016/j.mser.2009.03.001

19. J. Tian, W. Wang, M. Babar Shahzad, W. Yan, Y. Shan, Z. Jiang and K. Yang, Materials 2017, 10, 1293.

DOI:10.3390/ma10111293

20. W. Garrison, JOM 1990, 42, 20-24.

DOI:10.1007/BF03220942

21. B. Yan, Y. Lin and F. Huang, International Journal of Machine Tools and Manufacture 2002, 42, 925-934.

4,8 DOI:10.1016/S0890-6955(02)00026-3

22. H. Tsai, B. Yan and F. Huang, International Journal of Machine Tools and Manufacture 2003, 43, 245-252.

DOI:10.1016/S0890-6955(02)00238-9

23. H. Sidhom, F. Ghanem, T. Amadou, G. Gonzalez and C. Braham, The international journal of advanced manufacturing technology 2013, 65, 141-153.

DOI:10.1007/s00170-012-4156-6

24. S. R. Arunachalam, S. E. G. Dorman, R. T. Buckley, N. A. Conrad and S. A. Fawaz, International Journal of Fatigue 2018, 111, 44-53. DOI:10.1016/j.ijfatigue.2018.02.005

25. V. R. Chundru, R. Koona and S. R. Pujari, Arabian Journal for Science and Engineering 2019, 44, 1425-1436.

DOI:10.1007/s13369-018-3561-z

26. A. Torres, C. Luis and I. Puertas, Journal of Alloys and Compounds 2017, 690, 337-347.

DOI:10.1016/j.jallcom.2016.08.110

27. G. Cusanelli, A. Hessler-Wyser, F. Bobard, R. Demellayer, R. Perez and R. Flükiger, Journal of Materials Processing DOI:10.1016/j.jmatprotec.2003.11.047

28. K. Abrol, Chemer CNC EDM Opetation Manual, 2018, 3, 118-164.

29. S. Lee and X. Li, Journal of materials processing Technology 2001, 115, 344-358. DOI:10.1016/S0924-0136(01)00992-X

30. U. Elaiyarasan, V. Satheeshkumar and C. Senthilkumar, Journal of the Mechanical Behavior of Materials 2020, 29, 69-76. DOI:10.1515/jmbm-2020-0007

31. A. Kumar, V. Kumar and J. Kumar, Machining Science and Technology 2014, 18, 47-77.

DOI:10.1080/10910344.2014.863632
32. J. E. Fuller, EG and G Rocky Flats, Inc., Golden, CO (United States), 1991.

33. H. T. Lee and T. Y. Tai, Journal of Materials Processing Technology 2003, 142, 676-683.

DOI:10.1016/S0924-0136(03)00688-5

34. C. Li, X. Xu, Y. Li, H. Tong, S. Ding, Q. Kong, L. Zhao and J. Ding, Journal of Alloys and Compounds 2019, 783, 95-102.

DOI:10.1016/j.jallcom.2018.12.283

35. T. Xi, M. B. Shahzad, D. Xu, Z. Sun, J. Zhao, C. Yang, M. Qi and K. Yang, Materials Science and Engineering: C 2017, 71, 1079-1085. DOI:10.1016/j.msec.2016.11.022

36. Y. Jiangnan, W. Lichang and S. Wenhao, Corrosion science 1992, 33, 851-859. DOI:10.1016/0010-938X(92)90049-9

37. E. E. Oguzie, J. Li, Y. Liu, D. Chen, Y. Li, K. Yang and F. Wang, Electrochimica Acta 2010, 55, 5028-5035.

DOI:10.1016/j.electacta.2010.04.015

38. T. Ujiro, S. Satoh, R. W. Staehle and W. H. Smyrl, Corrosion Science 2001, 43, 2185-2200.

DOI:10.1016/S0010-938X(01)00008-7

39. E. E. Oguzie, J. Li, Y. Liu, D. Chen, Y. Li, K. Yang and F. Wang, Journal of materials science 2010, 45, 5902-5909.

DOI:10.1007/s10853-010-4669-Z

40. T. Sourisseau, E. Chauveau and B. Baroux, Corrosion Science 2005, 47, 1097-1117. DOI:10.1016/j.corsci.2004.05.024

41. G. Grimvall, Book Thermophysical properties of materials, Elsevier, 1999. DOI:10.1016/j.heliyon.2017.e00408

42. C. Fang and M. van Huis, Heliyon 2017, 3, e00408. DOI: $10.1016 /$ j.heliyon.2017. e00408

43. W. Dawson and F. Sale, Metallurgical Transactions A 1977, 8 , 15-18. DOI:10.1007/BF02677258

44. I. Nikolaenko and M. Turchanin, Metallurgical and Materials Transactions B 1997, 28, 1119-1130.

DOI:10.1007/s11663-997-0068-5 


\section{Povzetek}

$\mathrm{V}$ tem delu je bil preučen vpliv prisotnosti in difuzije bakra z elektrode orodja na površino iz EDMed nerjavečega jekla (SS) z uporabo elektrokemične impedančne spektroskopije (EIS), rentgenske difrakcije (XRD), kvantometrske analize in optične mikroskopije. Metoda Taguchi je bila uporabljena za preučevanje učinkov časov pulzov (ton, toff), razelektritvenega toka (I) in celotnega časa obdelave $(\tau)$ na kemično sestavo, mikrostrukturo, mikrorazpoke in elektrokemijsko korozijo obdelovancev iz EDMed nerjavečega jekla. Rezultati kažejo, da spreminjanje obdelovalnih parametrov spremeni kemično sestavo obdelovancev. S povečanjem razelektritvenega toka in zmanjšanjem časa pulza ton, baker in ogljik difundirata na površino obdelovanca. Posledično se spremeni kemična sestava površine obdelovanca, kar vodi do povečanja korozijske odpornosti. XRD analiza je pokazala tvorbo $\mathrm{Fe}_{2} \mathrm{C}, \mathrm{Cr}_{3} \mathrm{C}_{2}$ in $\mathrm{CuNi}$. Poleg tega se pri višjih vrednostih razelektritvenega toka in razmerja ton/toff mikro razpoke širijo po površini obdelovanca. 